I950-1977, and the 1979 January-June Records, this volume is intended to be a '... research tool ... for librarians and booksellers in special areas' (p. ix).

For problems inherent in the use of this database and of the LC subject classification, the reader is referred to the review by Irene R. Schechter (ARLIS/NA Newsletter, vol. 8 (summer 1980): pp. I43-I44).

The full entry, with imprint, series, Lc class number, Dewey number, price, and ISBN, appears in the subject index, the largest section of the volume. There is an in-print index by title, with binding, price, ISBN, publisher, but without author. An author index and a title index refer to the page numbers in the subject section, where up to four columns of print need to be scanned to find the required entry. Books for children are included, and 'Art Books' is liberally interpreted. These four sections have no name references; Le Corbusier (if this is the first word of the title) in the title section will lead to the subject entries under Jeanneret-Gris.

There follow two new sections compiled specially for this volume, not formerly in the databases. The 'Geographic Guide to Museums' is arranged by country, then by name of the institution, with address. In case of identical names (e.g., 'Pinacoteca Communale', 'Heimatmuseum') the list must be scanned. To find institutions located in one city, the entire country needs to be checked. Canada has $25 \mathrm{I}$ entries, including twelve name references.

The 'Permanent Collection Catalog Index' is the most innovative feature. Arrangement is by title of the institution; imprint, ISBN, and price are given; for street address the 'Geographic Guide to Museums' needs to be consulted. This listing is not covered by the subject index. For example, a catalogue on Henry Fuseli by the Tate Gallery will be found here under the Tate Gallery, but not in the subject index under Fuseli. These last two sections have name references.

While this work does not offer complete coverage, it appears to be a very useful introductory reference tool for smaller and medium-size public libraries, art galleries, booksellers, etc., especially where there is no ready access to more specialized tools such as the Répertoire international de la littérature de l'art. General readers, teachers, and antique collectors would also find it helpful for browsing and selection. Focusing attention on the wealth of material in museum and art gallery catalogues is a particularly welcome feature that adds much to its value.

EVE ALBRICH

(Dr. Albrich is Music/Art Librarian, Queen's University, Kingston, and formerly Music Cataloguer with the same institution.)

Union List of Serials in Fine Arts in Canadian Libraries / Inventaire des publications en série dans le domaine des beaux-arts dans les bibliothèques canadiennes. Ottawa: National Library of Canada, Union Catalogue of Serials Division / Bibliothèque nationale du Canada, Division du catalogue collectif des publications en série, I978. vii, 236 p., paper, \$II.25 (Canada), \$13.50 (other countries) IsBN 0-660-50I3I-7

Librarians and researchers in all fields of the fine arts will welcome this compilation, which is the fifth selective list to be published by the National Library of Canada in the period from 1974 to 1978 . This union list complements the survey of fine arts library resources in Canada published by the National Library in 1978.

This compilation does not purport to be a comprehensive listing of all fine arts serials 
held by libraries in Canada. However, it includes all serials indexed by eight of the major indexes and held in Canadian libraries. The very wide scope of the union list is evident by the fact that the library holdings of almost two hundred libraries from the National Library's Union Catalogue of Serials, two checklists of over three hundred titles completed by eighty libraries for the fine arts survey, and special serials lists and individual reports prepared by twenty libraries for this union list were all drawn upon as sources.

The entries for distinctive titles in this compilation are arranged alphabetically. Non-distinctive or generic titles (for example, 'Bulletin', 'Journal', 'Record', etc.) published by associations or corporate bodies appear under the name of the body. French or other Romance language serials are entered in French. English notes have been used for all serials published in other languages. Entries in both English and French have been used for titles published in both languages.

Each entry contains the IssN number (when available) and other standard union list information: title, place of publication, and notes regarding beginning date and other important data such as change of title and the society or body under whose auspices it is published. Finally, there are the symbols of the Canadian libraries represented in the list and the holdings information.

Nancy E. Brodie, Chief of the Union Catalogue of Serials Division, has written a very clear and concise Introduction for this compilation. The Explanatory Notes are well organized and easy to use. The information is clearly and simply presented throughout the work. The format is attractive.

Research and interlibrary loan librarians can only hope that the staff of the National Library of Canada continue to compile valuable reference tools of this nature.

GEORGE F. HENDERSON

\section{Canadian Writers}

Before the Flood: Hugh Hood's Work in Progress. [cover title] Edited by J.R. (Tim) Struthers. [Downsview, Ontario: Ecw Press, Stong College, York University, I979] 294 p., paper, \$7.50 ISBN 0-920802-OO-I

This book is a celebration of sorts. It is a work in progress about the Canadian writer Hugh Hood's works in progress. To find the full title the reader must take what is presented on the front cover, add to it and subtract what appears on the back cover, and the result is Before the Flood: Our Exagmination Round His Factification for Incamination of Hugh Hood's Work in Progress. According to his own account Hood would be a James Joyce, a Leo Tolstoy, a Marcel Proust and '... it will do a lot for the country'. It is not for the bibliographer to debate Hugh Hood's merits as a potential major writer, although one wonders if it is the habit of writers in any country to proclaim in mid-career that they intend to be 'major' and by doing so will make it 'marvellous for Canada' or any other place. This possibility is of interest to all of us, even bibliographers.

Before the Flood's subtitle is borrowed from a somewhat similar collection of essays devoted to the writings of James Joyce, which appeared in Paris in 1929. Our Exagmination Round His Factification for Incamination of Work in Progress had as its contributors Samuel Beckett, Frank Budgen, Stuart Gilbert, Eugene Jolas, and William Carlos Williams, amongst others. It also contained 'Letters of Protest' by G.V.L. Slingsby and Vladimir Dixon (both by Joyce?) [see Slocum and Cahoon, A Bibliography of James Joyce, $\mathrm{BIO}$ ]. There is nothing bordering on protest, phoney or otherwise, in the Hugh 